\title{
Maria as anti-tipe van die verbondsark in Lukas 1:39-56: 'n Uitdaging tot Protestantse herbesinning van die Marialogie
}

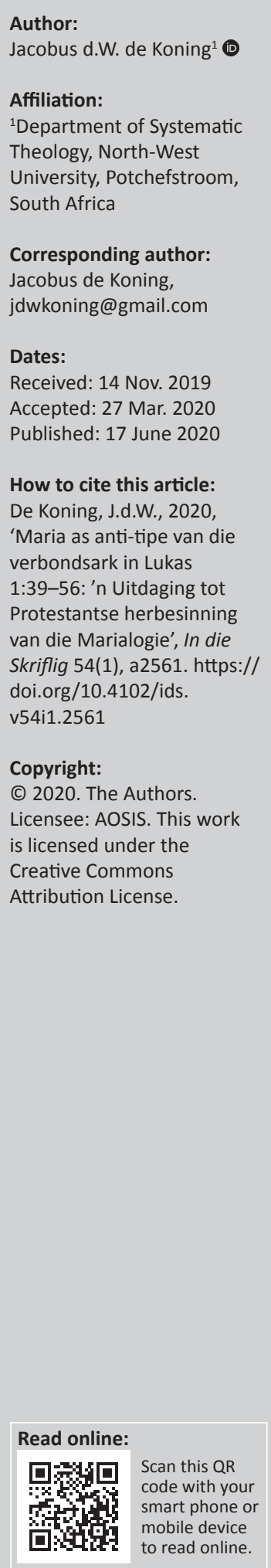

\begin{abstract}
Mary as anti-type of the ark of the Covenant in Luke 1:39-56: A challenge to Protestant reconsideration of Mariology. In this article, an attempt is made to indicate, that a typological reading of Luke 1:39-56 suggests that Mary should be understood as an anti-type of the Ark of the Covenant by the reader. It accordingly forces Protestants to reconsider the Mariology. After considering the historical and theological significance of the Ark of the Covenant in the Old Testament canon, the phenomenon of typology and the role of the reader, as well as text interpretation in Judaism and early Christianity, came under scrutiny. A look at the Protoevangelium of James followed and confirmed the possibility of a different reading of Mary in Luke. Luke 1:39-56 was then examined. By way of this examination, it is indicated that when Luke 1:39-56 is read in conjunction with 2 Samuel 6:1-13, 1 Chronicles 15:28, 16:4 and 2 Chronicles 5:13, Mary clearly emerges from the paint as an anti-type of the Ark of the Covenant. This conclusion, which is also visible in some fathers of the church, is then tested against the eschatology found in the New Testament. Finally, the implications of this insight and the challenge it poses to the relationship between Protestantism and Roman Catholicism are highlighted.
\end{abstract}

Keywords: Mariology; Mary; typology; Ark of the Covenant; Luke 1:39-56.

\section{Inleiding}

Marialogie en Protestantisme is nie bedmaats nie. Dit is te verstane. Die vier leerstukke van die Rooms-Katolieke Kerk met betrekking tot Maria ${ }^{1}$ en die vyf solae van die Reformasie kan oënskynlik net nie onder dieselfde dak gebring word nie. Die siening dat Maria Theotokos [draer van God] is, die gedagte van die sogenaamde 'onbevlekte' ontvangenis wat impliseer dat Maria geen erfsonde gehad het nie, sowel as die siening dat sy ook met liggaam en siel verheerlik is en na die hemel opgevaar het, bring die Marialogie en die Reformasie se solus Christus nie net in botsing nie, maar ook in stryd met mekaar. Veroorsaak die omhelsing van die vier Roomse leerstukke nie onvermydelik dat redding nie meer deur Christus alleen is nie? Trouens, rig dit nie vernietigende skade aan sola gratia en sola fide nie? Meer deurslaggewend: Protestante het al dikwels verwys na die besluit by die sinode van Efese in 431 n.C., waar besluit is om Maria Theotokos eerder as Christotokos te noem, as die oorsprong van die geneigdheid by Katolieke om in 'n verering te verval wat aan die aanbidding van Maria grens (Barth 1965:59-62).

Dit is daarom te verstane dat, alhoewel hervormers soos Luther, Zwingli en Calvyn voortgegaan het om Maria te vereer (nie te aanbid nie), hulle opvolgers - in 'n poging om sola Scriptura te handhaaf - uiteindelik tot die slotsom gekom het dat, behalwe vir die maagdelike geboorte, alle ander Maria-leerstellings oorboord gegooi moet word (Oberman 1971:274-288).

Dit is tragies dat, ten spyte van al die pogings van Katolieke kant om oordrewe skeeftrekkings ${ }^{2}$ reg te stel (Shelton 2016:5), daar van Protestantse kant steeds weggedeins word van enige ernstige omgang met die Skrif om, wat die Marialogie betref, nader aan die Katolieke te beweeg. Ter verdediging van hierdie Protestantse optrede, kan na George (2004:116-117) se opmerkings verwys word. Hy noem dat sola Scriptura 'n 'pruning effect' op Protestantisme gehad het, en hy gaan so ver as om te noem dat die verwaarlosing van Maria 'n 'ecclesiological hardening of arteries' in

1. Daar is vier leerstukke oor Maria wat vir die Rooms-Katoliek van uiterste belang is. Die erste is die uitspraak dat Maria, (Theotokos), draer van God of moeder van God is, wat reeds by die Konsilie van Efese in 431 n.C. gemaak is. Sy word as die maagd verheerlik wat die Seun van God in die wêreld gebring het. Daarom is sy natuurlik heilig en sondeloos (Panagia). Die tweede is dat Maria altyd ' $n$ maagd gebly het (voor, tydens Maria, wat beteken dat sy geen erfornde gehat die uaria na liggaam en siel verheerlik is om by die opgestane Christus te wees (die leerstuk van die hemelvaart van Maria) wat deur Pous Pius XI in 1950 aangekondig is (vgl. Shelton 2016:2)

2.Hier kan spesifiek gedink word aan die Tweede Vatikaanse Konsilie, Lumen gentium (Dogmatic Constitution of the Church), 21 November 1964, waar besluit is om die Mariologie as deel van Ekklesiologie eerder as'n onafhanklike teologiese locus te hanteer. 
Protestantisme veroorsaak het, wat aan 'n Protestantse óóreaksie op Katolieke óór-beklemtoning te wyte is (George 2004:116-117).

Die feit bly staan: Marialogie is steeds grotendeels 'n Protestantse taboe veral vir die gewone lidmaat en dit is 'n muur van skeiding tussen Katoliek en Protestant. Congar (1964:100) het van 'the insuperable wall of ... devotion to the Virgin Mary' gepraat. Trouens, soos Gerdes (1968:38) dit gestel het: 'For many, the very word Mariology suggests Mariolatry'.

In hierdie artikel gaan daar gepoog word om aan te toon dat die Marialogie nie te vinnig as 'n verwerping van sola Scriptura en dit wat dááruit voortvloei gesien moet word nie. Trouens, sola Scriptura vereis 'n Protestantse herbesin oor Maria.

Om hierdie stelling te verdedig, word eerstens ' $n$ kort historiese en teologiese oorsig oor die verbondsark gegee. Tipologie as 'n geldige manier van omgang met die Skrif binne die sola Scriptura-belydenis sal volgende aan die beurt kom en die leser se rol in die lees van tipologiese materiaal sal aangeraak word. Om die rol van die leser, veral die antieke leser, nog meer te belig, sal die vroeë Christendom, Judaïsme en teksinterpretasie onder die vergrootglas geplaas word voordat enkele tendense in die proto-evangelie van Jakobus se hantering van Maria, wat in hierdie dampkring ontstaan het, bekyk word. Daarna sal die onmiddellike konteks van Lukas 1:39-56 onder die loep kom om aan te toon dat die geskiedenis van Israel en die Joodse verstaan daarvan duidelik 'n rol in Lukas se eerste hoofstuk speel. Lukas se weergawe van Elisabet se besoek aan Maria in Lukas 1:39-56 sal daarna op die tafel geplaas word om aan te toon dat Maria in hierdie gedeelte as die anti-tipe van die verbondsark figureer gegewe die aggadah-interpretiewe dampkring waarin Lukas saamgestel is. In die lig van hierdie tipologie sal die artikel poog om 'n oproep te wees tot Protestante vir 'n skrifgegronde herbesinning van Maria. Anders gestel: gedeeltes soos hierdie behoort die basis te vorm vir 'n oop gesprek tussen Katolieke en Protestante sodat daar ook tot groter eenheid beweeg kan word op 'n terrein wat in die verlede tot geweldige skeiding gelei het. Hierdie siening van Maria is deur vroeë kerkvaders gedeel. Stem dit egter ooreen met die eskatologiese verstaan van die kerk in die Nuwe Testament? Nadat die antwoord in die eskatologie gevind is, poog die artikel om 'n oproep te wees tot Protestante vir 'n Skrifgegronde herbesinning van Maria.

\section{Die verbondsark in historiese en teologiese perspektief}

Die verbondsark, 'n eenvoudige konstruksie wat styl en samestelling betref, was sekerlik die waardevolste en mees betekenisvolle besitting van die Jode in die Ou Testament: 'n houtkrat (ark) ongeveer drie voet lank en twee voet in breedte en hoogte, gemaak van onder meer onverganklike akasiahout en en van binne en buite met goud oorgetrek.
Die inhoud was betekenisvol. Die tafels met die tien gebooie en waarskynlik 'n houer gevul met manna uit die woestynomswerwings (Heb 9:4), asook Aäron se staf, is hierin gevind (Flanagan 1961:370).

Insiggewend was die 'troon' bo-op. 'n Blok goud met dieselfde lengte en breedte as die ark self. Dat dit as die troon van God gesien is, word duidelik uit verskeie gedeeltes (1 Sam 4:4; 2 Sam 6:2; 2 Kon 19:15, ens.). In na-ballingskapse tye is daar beloof dat Jerusalem self die troon van Jahweh sal word. Dit sou dan die bestaan van die ark oorbodig maak (Jer 3:16 e.v.). In die profesie van Esegiël word daar eksplisiet genoem dat die tempel die troon sowel as die voetbank van die Here is (Eseg 43:7). Tog moet onthou word dat die ark in die Ou Testament altyd beskryf word as 'n ark (Latyn, arca, 'chest') en nooit as 'n troon of sitplek nie. Die verwysings na 'n troon moet figuurlik geneem word.

Aan elke kant van hierdie 'goue blok' is 'n gerub aangebring. Die goue blok was ook die plek van versoening waar die bloed van die offerdiere tydens die groot versoendag gesprinkel is (Lev 16:14; Metzler 2016:12-15).

In die lig van hierdie beskrywings word die verbondsark teologies geïnterpreteer as die verlenging of beliggaming van die teenwoordigheid van Jahweh (Flanagan 1961:371). Hierdie feit word duidelik gesien toe die tent-tabernakel opgerig is en as beskerming van die ark gedien het. Die wolk van God se teenwoordigheid het onmiddellik die tent gevul (Eks 40:35). Vanaf hierdie moment het God met die verteenwoordiger van sy volk gepraat vanaf die versoendeksel, van tussenuit die twee gerubs wat op die ark van die getuienis was ... (Eks 25:22). Die ark word dus as die plek gesien waar die Woord van God wat in die vorm van die tablette in die ark gevind word, gehoor word en dan 'n invloed uitoefen (Flanagan 1961:371).

Die verhaal van die verbondsark is natuurlik die verhaal van Israel self. 'n Verhaal waarin die angswekkende krag van hierdie verbondsark, die plek waar God teenwoordig is, duidelik na vore kom, maar ook die seën wat dit bring (Num 10:35; Jos 3:14-17; 6:6 e.v.; 2 Sam 6:9-11; Metzler 2016:14).

Nadat Salomo die verbondsark in die allerheiligste geplaas het, word niks meer van die ark gehoor nie. Daar mag egter sommige indirekte verwysings na die ark in latere bybelse narratief wees (Metzler 2016:18-20). Die verwysing na die ark in Jeremia 3:16 kan geneem word as 'n aanduiding dat die ark as 'n magtige teenwoordigheid in Jerusalem beskou is, tot en met die vernietiging van die tempel in 586 v.C. Tog is dit fassinerend dat die verbondsark nie gesien word in die lys van items wat deur die Babiloniërs gesteel is toe die tempel van Salomo vernietig is nie (2 Kon 25:13-17; Jer 52:17-23).

In Jeremia 3:16 praat die profeet oor 'n tyd wanneer die ark vergete sal wees:

En as julle vermenigvuldig en vrugbaar word in die land in dié dae, spreek die HERE, dan sal hulle nie meer sê: Die verbondsark 
van die HERE nie. Ook sal dit in die hart nie opkom nie, en hulle sal daaraan nie dink en dit nie soek nie, en dit sal nie weer gemaak word nie

Wat uiteindelik van die ark geword het, bly 'n misterie. Die mees waarskynlike is dat dit vernietig is, veral as die frase 'en dit sal nie weer gemaak word nie', in ag geneem word (Day 2005:263).

Volgens 2 Makkabeërs 2:4-5, was Jeremia verantwoordelik vir die wegsteek en verseëling van die verbondsark in 'n geheime grot naby die berg waar Moses gesterf het. Jeremia sou hulle berispe het en dit duidelik gemaak het dat die plek onbekend sal bly totdat God weer sy mense sou versamel en sy barmhartigheid sou toon. Die belofte word ook gemaak dat Jahwe alles sal duidelik maak (openbaar) en dat sy heerlikheid en die wolk weer sal verskyn (2 Makk 2:7-8).

In die Kanon verskyn die ark vir die laaste keer in Openbaring 11:19:

En die tempel van God het in die hemel oopgegaan, en sy verbondsark is in sy tempel gesien, en daar was weerligte en stemme en donderslae en aardbewing en groot hael.

Met hierdie agtergrond ten opsigte van die historiese verbondsark, kan nou nagespeur word hoe hierdie ark weer op tipologiese wyse in die geskiedenis van die kerk verskyn en funksioneer.

\section{Tipologie in die Nuwe Testament: Begripsverklaring}

Tipologie in hierdie artikel dui op die metode van Bybelse interpretasie waar'n element wat in die Ou Testament gevind word, gesien word as 'n voorafskaduwing van een wat in die Nuwe Testament gevind word. Die aanvanklike element staan bekend as die tipe, en die vervulling daarvan is die anti-tipe.

Dit is met hierdie basiese begrip as agtergrond dat gekyk word na 'n perikoop in Lukas se evangelie. 'n Verdere ontvouing van tipologie word voorts gedoen.

Enige poging om die fondasies van die konseptuele raamwerk van die Nuwe Testament te verstaan, moet rekening hou met die Joodse agtergrond van die Nuwe Testament.

Robinson (1965) het jare gelede reeds die volgende betekenisvolle opmerking in hierdie verband gemaak:

The Jews viewed history as a cyclic process: they tended always to see it not as a succession of separate incidents, but as a repetition with numerous variations, of a few basic themes. (p. 105)

So gesien, is herhaling en tipologie dus belangrike komponente van Bybelse interpretasie ook binne die sola Scriptura belydenis.
'Typology is not concerned with words', skryf Baker (2010:179) 'but with historical facts - events, people, institutions'. Tibor Fabiny (2009:144) som Baker se definisie van tipologie op as 'n manier om geskiedenis te verstaan, eerder as 'n metode om die teks self te bestudeer.

Tipologie is daarom nie bloot ' $n$ bemoeiing met verbale sinspelings of literêre verwysings nie. Trouens, dit is veeleer besorg oor die onderliggende realiteite wat bespreek word. Inderdaad is tipologie afhanklik van tipes wat legitieme en konkrete betekenis het indien dit behoorlik wil funksioneer. Gebeure soos die eksodus word daarom paradigmaties vir die manier waarop Ou-Testamentiese skrywers God se verlossende handelinge verstaan, en persone soos Adam of selfs instellings soos die tempel word die voorbeeld waarmee Jesus vergelyk word. Baker (2010:180) is weereens behulpsaam as hy 'n tipe definieer as 'a biblical event, person or institution which serves as an example or pattern for other events, persons or institutions'. Juis daarom moet tipologie nie met allegorie verwar word nie. Gentry en Wellum (2015) onderskei tipologie van allegorie op die volgende wyse:

Typology is grounded in history, the text, and intertextual development, where various 'persons, events, and institutions,' are intended by God to correspond to each other, while allegory assumes none of these things. (p. 38)

Allegorie poog om verby die feite van 'n gebeure te kyk om 'n dieper betekenis te verstaan. Tipologie aan die ander kant probeerdiefeitevan'ngebeurevergelyk metooreenstemmende persone, gebeure en institusies in die bybelse verhaal om daaruit te leer en dit te verstaan.

Vanuit die perspektief van die menslike outeurs van die Skrif, kan gesê word dat baie hulleself sien as instrumente wat hierdie interpretatiewe tradisie voortsit. Hulle vertel hulle stories op so 'n wyse dat die leser 'n vroeëre persoon, gebeure, instelling of simbool daarin sal raaksien. Robinson (1965:105) beskryf hierdie metodologie as 'midrashic', wat hy ook in sy artikel gebruik 'to indicate the way in which later events were seen as a heightened repetition of earlier ones'.

In hierdie artikel word aangedui dat dit presies is wat Lukas in sy perikoop in Lukas 1:39-56 doen. Lukas, die 'werklike outeur' van die boek Lukas is natuurlik 'n anonieme Christen van die laat eerste eeu wat waarskynlik 'n heiden was, 'n metgesel van Paulus, wat moontlik 'n dokter kon wees. Knight (2005:38) dui egter aan dat Lukas soos ons hom ken, ten diepste ' $n$ 'geïmpliseerde outeur' is. Dit is die outeur soos hy geskep word deur die leservan die narratief. Onderskeibaar van die geïmpliseerde outeur (en die karakters) is die verteller. Die verteller is die retoriese agent wat die leser deur die narratief begelei en wat die leser aan sy wêreld en karakters voorstel, en natuurlik ook die perspektief verskaf van waaruit die aksie kan of moet gesien word. Dit is die verteller van hierdie perikoop wat sy leser aan Maria as antitipe van die verbondsark wil voorstel. 
Op hierdie punt moet gekyk word na die rol van die leser in tipologie.

\section{Die leser van Lukas en tipologie}

Resente studies vestig al meer die aandag op die leser as 'n betekenisvolle agent in die interpretasie van ' $n$ teks (Knight 2005:36). 'n Teks word lewendig in die leesgebeure. 'n Deel van die leser se taak is om die tekens wat die outeur in sy narratief geplaas het, te ontsyfer. ' $n$ Teken is 'n simbool van betekenis. ' $n$ Versameling tekens vorm ' $n$ patroon van denke. 'n Teks kondisioneer sy leser om op 'n sekere manier te reageer, byvoorbeeld deur die opmerkings en vooropgestelde idees van die verteller. Die finale versameling van betekenis rus egter by die leser en nie by die outeur nie. Dit sou beteken dat die leser selfs betekenis in die teks kan vind wat nie bewustelik deur die outeur daarin geplaas is nie.

Dit is van kardinale belang om kennis te neem van ' $\mathrm{n}$ manier van lees, van omgaan met die teks wat in die vroeë kerk bestaan het, om te begryp dat ' $n$ tipologiese lees van Maria as anti-tipe van die verbondsark geensins ' $n$ vergesogte teorie is nie.

\section{Die vroeë Christendom, Judaïsme en teksinterpretasie}

Louth (2016:434-436) maak die stelling dat die verskynsel van pseudonimiteit (die gebruik van 'n skuilnaam) in die apokriewe Nuwe-Testamentiese tradisie, eksplisiet of implisiet, gedien het om die aanspraak te bevestig dat daar in hierdie geskrifte 'n geheime apostoliese tradisie bewaar gebly het. Dit is ' $n$ tradisie wat na Jesus teruggevoer kan word, maar nie in die kanonieke Nuwe Testament bewaar is nie. Die aanspraak is gemaak dat daar in hierdie geskrifte ' $n$ apostoliese lering gevind kan word wat nie algemeen bekendgemaak is nie. Net 'n sekere groep het hiervan kennis. Jesus se lering in 'n gedeelte soos Markus 4:10-12 waar hy die stelling maak dat 'Aan julle is dit gegee om die verborgenheid van die koninkryk van God te ken', asook gedeeltes soos Lukas 24:27, 45 waar Jesus spesiale lering vir die dissipels gee, het natuurlik deel van die begronding van hierdie siening uitgemaak.

Stroumsa (2005:3-7) vors 'esoteriese' tradisies in die Christendom na, en kom tot die konklusie dat die oorsprong daarvan juis in hierdie eerste-eeuse Judaïsme gevind word. Hy wys daarop dat 'esoteriese' leerstellings deur verskeie groepe aangeneem en ontwikkel is en vandag bekend staan as 'Gnostisisme'.

Reeds teen die einde van die tweede eeu is hierdie esoteriese lerings deur die kerkvaders verwerp en het uiteindelik verdwyn, maar latere mistiese tradisies gebruik weer elemente hiervan. Kenmerkend egter bly die gedagte van 'n 'spesiale' groep.

Louth (2016:426-437) maak 'n uiters belangrike opmerking wanneer hy noem dat 'esoteries' nie hoef te verwys na spesifieke leerstellings wat net beskore is vir 'n 'elite' groep wat duidelik geïdentifiseer kan word nie. Louth (2016) stel duidelik dat 'esoteric might simply mean the hidden significance that lies behind public doctrine and public scriptures, and the "elite" those who are interested enough to want to explore it'.

So gesien, is daar geen diskontinuïteit tussen die gewone gelowiges wat bloot die waarheid van die geloof aanvaar, en diegene wat dit dieper wil ontdek nie. ${ }^{3}$

Die onderskeid tussen aggadah en halakah in die Joodse midrasj-eksegetiese tradisie, is daarom vir Louth (2016:437438) van hulp om te verduidelik hoe apokriewe geskrifte vir ons iets kan leer omtrent die lees van die kanoniese geskrifte, ook as dit kom by die Mariologie. Halakah is met die ontdek van praktiese voorskrifte uit die Tora gemoeid, terwyl die aggadah meer met 'providing an imaginative sense of belonging to the world of the narrative of biblical, and more broadly, Jewish history' gemoeid is (Louth 2016:437).

In die lig hiervan is dit uiters relevant om van Avery-Peck, Evan en Nauser se werk, Earliest Christianity within the boundaries of Judaism, kennis te neem. Hierin is artikels opgeneem wat aan Bruce Clinton, spesialis in Aramees en die targum, opgedra is. In een van hierdie artikels analiseer Aus (2016:241-254) sewe motiewe of ekwivalente daarvan in Lukas 15:11-32 wat in die Joodse kommentaar op 2 Samuel 6 binne die aggadah eksegetiese tradisie voorkom.

Hy kom tot die konklusie dat Jesus van die Lukas-evangelie, as profeet en meester storieverteller, ongetwyfeld hierdie Joodse interpretasies van die terugkeer van die ark na Jerusalem gebruik het as agtergrond vir sy vertelling van die oorvloedige liefde van die Vader vir die verlore seun wat teruggekeer het. Die ooreenkomste is eenvoudig te verstommend duidelik om dit te ontken (Aus 2016:254).

Hierdie bydrae is insiggewend vir hierdie artikel, aangesien dit die moontlikheid versterk dat Lukas in Lukas 1:39-65, ook 2 Samuel 6 se verbondsark-gedeelte as agtergrond kon gebruik het om sy lesers tot ' $n$ tipologiese lees van Maria as anti-tipe van die verbondsark te begelei. Dat Lukas se eerste lesers tot genoemde slotsom sou kom, word deur die volgende opmerking van Knight (2005) versterk:

Luke's heavy use of biblical Greek, and the implied readers' presumed knowledge of the Septuagint, identifies them as people with expertise in this area and thus as Christians rather than as interested Romans who had not been instructed in Jewish matters. (p. 7)

Du Plessis (1980:157) toon aan dat Lukas 1-2 heelwat Semitiese elemente bevat wat waarskynlik te danke is aan die skriftelike bronne waarvan hy gebruik gemaak het en waarvan hy die styl behou het. Hy meen dat Lukas van al die Sinoptici die meeste deur die Septuagint beïnvloed is.

Dit is interessant dat geleerdes sedert die middel negentigerjare van die vorige eeu al meer na die vroeë 3.Louth (2016:137) dui ook breedvoerig aan hoe Clement van Alexandrië hierdie

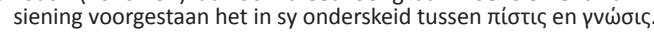


Christendom as 'n nuwe vorm van Judaïsme verwys - 'n vorm wat sy eie redevoering en diskoers ${ }^{4}$ ontwikkel het (Robbins 2015:353-362).

Dit maak in die lig hiervan heeltemal sin dat gedeeltes oor die priesterlike doen en late, die tempel en die verbondsark in die agtergrond van Lukas se verhaal oor Maria en die geboorte van Jesus lê. Die feit dat Lukas afskop met die priester Sagaria wat ' $n$ offer in die tempel bring (Luk 1:9), bevestig dit (Robbins 2015:361).

Hierdie voorafgaande opmerkings bevestig die feit dat wanneer Lukas se eerste hoofstukke gelees word, 'n tipologiese lees daarvan in ooreenstemming sal wees met die wyse waarop die vroeë Christelike skrywers hulle teks saamgestel en bedoel het om gelees te word. Daar lê dus 'verborge' betekenis in die teks, wat met 'n tipologiese lees ontdek kan word deur diegene wat genoeg belangstel om dit te ontgin. Dit lyk dus asof daar sekerlik meer as een legitieme manier is om Lukas se verhaal van Maria en die geboorte van Jesus te lees. Die betoog is egter dat 'n tipologiese lees van Lukas 1:39-56, in die lig van die opmerkings oor die invloed van Judaïsme en Judaïstiese (midrasj) eksegese (spesifiek die aggadah eksegetiese tradisie) in die vroeë Christendom, ongetwyfeld Maria as anti-tipe van die verbondsark sou raaksien.

Op hierdie punt is dit belangrik om na 'n apokriewe teks uit dieselfde tydperk te kyk waarin die tipologie van Maria as anti-tipe van die verbondsark ook uit die verf te voorskyn kom.

\section{Die belang van die proto-evangelie van Jakobus}

Alhoewel die apokriewe geskrif, die proto-evangelie van Jakobus, 'n enorme invloed op die Christen se verstaan van Maria gehad het, is die geskrif grootliks onbekend buite akademiese kringe (Gaventa 1995:100-106). Dit is besonder moeilik om met absolute sekerheid iets oor die datum van ontstaan en die skrywer van hierdie narratiewe dokument te sê. Hierdie geskrif maak daarop aanspraak dat die skrywer Jakobus, die broer van Jesus sou wees. Hy is natuurlik 'n stiefbroer, aangesien hy noodwendig een van Josef se seuns uit 'n vorige huwelik moes wees. 'n Verwysing na die oproer wat op die dood van Herodes (waarskynlik Herodes die Grote) gevolg het, sou beteken dat die skrywer die boek Jakobus saamgestel het terwyl Jesus 'n baba was wat natuurlik op betroubaarheid dui wat die materiaal omtrent die geboorte van Jesus betref. Navorsing toon egter dat die proto-evangelie

4.In sy analise hiervan, toon Robbins (2015:353-362) aan dat daar in hierdie diskoers ' $n$ vermenging van 6 onderskeibare 'rhetorolects' onderskei kan word: wysheid, profeties, apokalipties, preskepping, wonder en priesterlik. ' $n$ 'Retorolek' is volgen hom 'a form of language variety or discourse identifiable on the basis of a distinctive configuration of themes, topics, reasonings, and argumentations' (Robbins 2015:356). 'Retorolekte' het twee dimensies: 'n retografie of grafies-geillustreerde verhaal en ook 'n retologie - 'n geloofsargumentasie wat die verhaal ondersteun. Retografie het weer twee dele, naamlik ' $n$ agtergrondnarratief wat inspeel op die voorgrondnarratief van die teks. In Christen-retografie is die agtergrondnarratief uit die Ou-Testamentiese storielyn afkomstig. Die bronne van Christelike retologie is die geloofsberedenerings van Judaïsme en die wyer Hellenistiese kultuur wat die Christelike narratief ondersteun. Afhangende van die historiese omstandighede, kan enige van hierdie 'retorolette' dominant wees of op die agtergrond gedruk word. Insiggewend vir hierdie studie, is die feit dat Robbins (2015:361) aandui dat die dominante 'retorolek' in Lukas-Handelinge, juis die priesterlike is! iewers aan die einde van die tweede eeu geskryf is. Die feit dat Origines aan die einde van die tweede en die begin derde eeu 'n aanduiding van vertroudheid met die geskrif toon, bevestig hierdie aanname (Gaventa 1995:107).

Die verstommende vrye manier waarop die kanoniese evangelies se inhoud aangewend word, dui daarop dat die geskrif tot stand gekom het na die samestelling van die kanoniese evangelies, maar voordat hulle kanoniese status ontvang het (Gaventa 1995:108). Dit is fassinerend dat die skrywer onafhanklik van die evangelies die Septuagint gebruik. Die uitgebreide gebruik van die Ou Testament mag die suspisie laat ontstaan dat die skrywer 'n Joodse Christen was, maar daar is heelwat in die proto-evangelie van Jakobus wat op die teenoorgestelde dui. Die outeur is byvoorbeeld verward wanneer dit kom by die Palestynse geografie. Daar kan met redelike sekerheid gesê word dat die proto-evangelie van Jakobus deur 'n heidense Christen geskryf is wat besondere aandag aan die Septuagint gegee het as middel om die kontinuïteit tussen Maria en die Joodse tradisies aan te toon (Gaventa 1995:108).

Die noue verhouding wat hierdie evangelie met die Evangelie van Lukas toon, is vir hierdie artikel belangrik. Daar is duidelike ooreenkomste wat konsepte, temas en ook sintaktiese verskynsels betref (Elliott 2005:48-67; Van Stempvoort 1964:410-426; Vorster 1988:262-75).

Hollman (2015:110-115) dui aan hoe die proto-evangelie Maria as die 'acceptable gift', 'sacred vessel' en die 'locus of divine presence' uitbeeld. Sy dui verder aan dat die struktuur van die proto-evangelie se verhaal van Maria se toewyding ooreenstem met die verhale van die drie groot bewegings van die verbondsark voordat dit deur Nebukadnesar weggevoer is.

Die Ou-Testamentiese gedeeltes wat hierdie bewegings hanteer, is in Eksodus 39-40, 1 Kronieke 15-16, 2 Samuel 6 en 2 Kronieke 5-7.

Hollman (2015:116-126) sien 'n algemene patroon in die vertellings van die bewegings van die ark en sy organiseer hierdie patroon volgens'n openings-, middel-en slotgedeelte. Maria as 'sacred vessel' se bewegings kan volgens haar duidelik in die proto-evangelie van Jakobus op dieselfde wyse as die beweging van die verbondsark in die $\mathrm{Ou}$ Testament georganiseer word.

Hierdie bydra van Hollman is insiggewend, alhoewel daar ook kritiek daarop geopper kan word (Hock 2015:267-270). Dit dui daarop dat die manier waarop daar in die protoevangelie met die historiese gebeure rondom Jesus en Maria omgegaan is aan die een kant, en die Septuagint se hantering van die verbondsark-gedeeltes aan die ander kant, duidelik op 'n tipologiese verstaan en hantering van Maria as anti-tipe van die verbondsark dui. Al sou die insigte van Hollman bevraagteken word, is dit steeds ' $n$ feit dat die protoevangelie van Jakobus baie duidelik op Maria gefokus is. Om 
Maria en die verbondsark in die evangelie van Lukas se hantering van Maria raak te sien, kan daarom ook nie vergesog wees nie. Indien Aus (2016:241-254) se werk aangaande die gebruik van die verbondsarkverhaal van 2 Samuel 6 in Lukas 15 ook in gedagte gehou word, word die waarskynlikheid 'n al groter sekerheid. Lukas het duidelik 'n affiniteit vir die verhaal van die verbondsark gehad. In hierdie artikel gaan vervolgens aangedui word dat 'n tipologiese hantering van Lukas 1:39-56 sekerlik tot 'n raaksien van die verbondsarkverhaal in die narratief omtrent Maria lei. Anders gestel: Maria as ant-tipe van die verbondsark kan inderdaad raakgelees word deur diegene wat dieper kyk met 'n aggadah-tipe eksegese.

\section{Maria as die verbondsark: Lukas 1:39-56 onder die loep}

Voordat Lukas 1:39-56 ondersoek word, gaan eers kortliks na die onmiddellike konteks van die gedeelte gekyk word.

\section{Johannes die Doper (Luk 1:5-25)}

Daar is reeds gewys op Robinson (1965:105) se uitspraak omtrent die Joodse siening van die geskiedenis as 'n sikliese proses: ' $n$ herhaling met baie variasies van ' $n$ paar basiese temas. In Lukas 1:5-25 is daar duidelike eggo's van die OuTestamentiese narratief van die volk Israel wat die plot van die verhaal stewig binne die tradisie van beloftes aan Israel plaas.

Die geboorte van 'n kind vir ou en onvrugbare ouers herroep sekerlik die geboorte van Simson (Rig 13), maar veral ook dié van Samuel (1 Sam 1-2). 1 Samuel begin met 'n onvrugbare vrou en 'n onvrugbare nasie. Die verbondsark word gesteel (1 Sam 4:11). Vir lank was daar geen openbaring van God nie. Dit is ook die geval ten tyde van Johannes se geboorte. Net soos beide genoemde figure Israel sou terugbring, so sou Johannes die Doper (1:16) dit ook doen. Soos (Knight 2005:73) dit stel: 'This is an appropriate introduction to the plot which concerns the eschatological restoration or reconstitution of Israel'.

\section{Die Lofsang van Maria (Magnificat; Luk 1:46-55)}

Alle generasies sou Maria geseënd noem (Luk 1:48), aangesien God groot dinge vir haar gedoen het (v. 49). Lukas beskryf in 1:50-55 wat God deur Jesus sal doen. Daar is natuurlik 'n sterk gedagte van 'n ommekeer wat sal plaasvind (Luk 1:51-53). Die magtiges sal van hulle trone afgeruk word en die hongeriges sal met goeie dinge gevul word. Dit antisipeer natuurlik Jesus se preek in Nasaret (Luk 4), waar Jesus dit duidelik maak dat Jesaja se eskatologiese profesie van die goeie nuus vir armes in sy koms tot vervulling kom (Luk 4:18-19). Daar is 'n interessante parallel tot hierdie tema van ommekeer in die sogenaamde The similitudes of Enoch (1 En. 37-71) uit die eerste eeu na Christus. In hierdie Joodse werk word die neerwerping van die magtiges in verband gebring met die hemelse troonbestyging van die Seun van die mens (bv. 1 En. 62).
Die belangrikheid daarvan vir hierdie artikel is daarin geleë dat die Magnificat ook 'n Joodse apokaliptiese agtergrond reflekteer. Dit is dan ook geensins vreemd om te merk dat die Magnificat met die feit eindig dat God se barmhartigheid oor Israel (die 'kinders van Abraham') vir ewig sal wees nie (Luk 1:54-55). Baie duidelik skryf Lukas dus binne 'n raamwerk waar die eskatologiese hoop binne die tradisie van die Joodse verstaan van God se beloftes aan Israel beweeg.

\section{Maria besoek Elisabet (Luk 1:39-56)}

Daar kan min twyfel bestaan dat Lukas se paragraaf oor Maria wat Elisabet besoek, eggo's van die verbondsark se terugkeer bevat. Daar is reeds na die Joodse apokaliptiese verwagting verwys wat onderliggend aan Lukas se werk lê. Dit lyk verder meer asof Lukas in hierdie gedeelte veral met 2 Samuel 6:1-13 in gedagte werk, terwyl daar ook eggo's van 1 Kronieke 15:28; 16:4 en 2 Kronieke 5:13 voorkom (vgl. Hahn 2001:63-64).

Verskeie eggo's word vervolgens uitgelig om Lukas se gebruik van tipologie aan te dui:

- In Lukas 1:35 sê die engel Gabriël die volgende:

Die Heilige Gees sal oor jou kom en die krag van die Allerhoogste

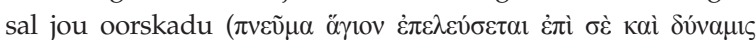

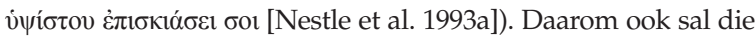
Heilige wat gebore word, Seun van God genoem word.

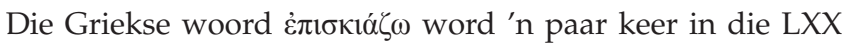
gebruik om na die wolk van heerlikheid te verwys wat die verbondsark in die tabernakel oorskadu het. Ons vind dit

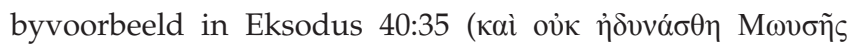

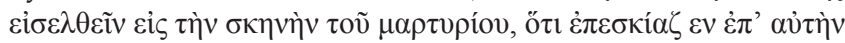

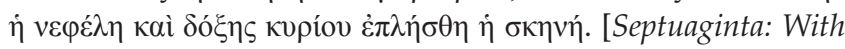
morphology 1996a]).

Die implikasie hiervan word nog duideliker indien die Joodseskatologiese verwagting, waarna reeds verwys is, in gedagte gehou word. Dit is fassinerend dat 2 Makkabeërs 2:4-8 (waarna reeds verwys is) na die feit verwys dat Jeremia die verbondsark sou versteek het en verklaar het dat die plek waar die ark is onbekend sal bly totdat die heerlikheid van die Here en die wolk sal verskyn!

- Maria sowel as die verbondsark is in Lukas 1 en 2 Samuel 6 op 'n tog na dieselfde heuwellandskap van Judea. Beide gebeure begin met die protagonis wat 'n beslissende besluit maak om na die berglandskap te gaan. 1 Samuel 6:2 lees: '... Dawid het hom klaargemaak en met al die mense opgetrek ...' En hulle het die ark van God op 'n nuwe wa vervoer en dit uit die huis van Abinádab, wat

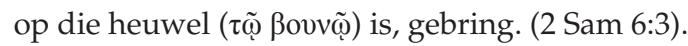

- Lukas vertel: 'En in daardie dae het Maria opgestaan en haastig na die bergstreek ( van Juda' (Luk 1:39).

- Wanneer Dawid die ark sien, verheug hy hom en roep uit: 'Hoe kan die ark van die HERE na my kom?' (2 Sam 6:9;

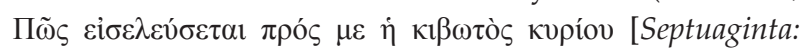
With morphology 1996b]). 
Elisabet weer roep in Lukas 1:43 uit: 'En wat het my oorgekom dat die moeder van my Here na my toe kom?'

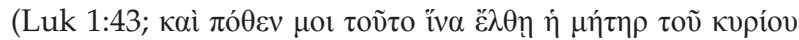

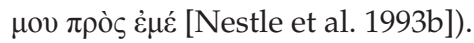

- Die ark sowel as Maria word met uitroepe van vreugde

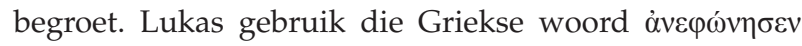
vir Elisabet se harde uitroep. Shelton (2016:128) wys op die fassinerende feit dat hierdie woord ' $n$ hapax legomenon in die Skrif is en in die Septuagint slegs gebruik word in die gevalle waar die verbondsark in Jerusalem inkom, in die tent in Jerusalem geplaas word en later in Salomo se tempel oorgeplaas word (1 Kron 15:28; 16:4; 2 Kron 5:13). Elisabet volg dus haar Levitiese voorgeslagte wat hulle stemme in vreugde verhef het by die terugkeer van die verbondsark.

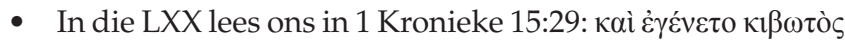

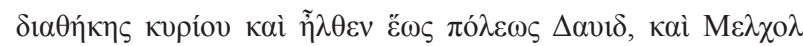

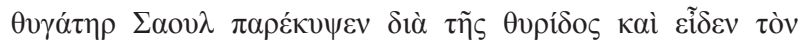

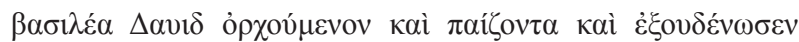

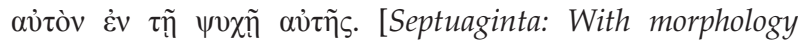
1996c].

- Dawid nader die verbondsark dus met uitroepe en hy dans en spring voor die verbondsark. Hy dra selfs die priesterlike skouerkleed. Wanneer Maria Elisabet nader, spring die ongebore Johannes die Doper op in haar

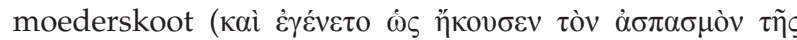

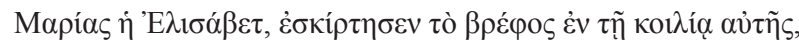

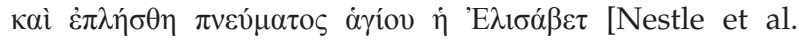
1993b]; Luk 1:41). Johannes was natuurlik uit die priesterlike lyn van Aäron. By beide is daar beweging en vreugde.

- Die verbondsark het volgens 2 Samuel 6:11 vir drie maande in die huis van Obed-Edom gebly: 'En die ark van die HERE het drie maande ( $\mu$ ñvas $\tau \rho \varepsilon \tilde{\varsigma} \varsigma)$ lank in die huis van Obed-Edom, die Gittiet, gebly, en die HERE het Obed-Edom en sy hele huis geseën.'

- Lukas lig ons in dat Maria vir drie maande in Elisabet se huis gebly het: 'En Maria het by haar omtrent drie maande

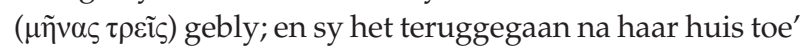
(Luk 1:56). Die feit dat die ark drie maande in die huis van Obed-Edom vertoef het, is insiggewend. Dit sou genoeg tyd wees om te wys dat die Here inderdaad die huis van Obed-Edom geseën het! Na hierdie drie maande begin swangerskap wys en sou die seën van die Here sodoende dus duidelik geword het (Metzler 2016:258-262; Laurentin 1986:56-58, 154-59; Villeneuve 2016; 255, 289).

- Die plek waar die ark in 2 Samuel 6:11 vertoef het, is

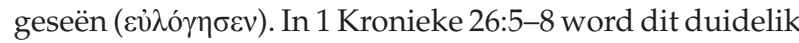
wat hierdie seën behels het wanneer daar uiteindelik 62 seuns vir Obed-Edom gebore word (Metzler 2016:253255). In die kort paragraaf in Lukas 1:39-56 gebruik Lukas

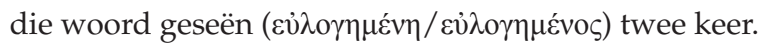

- Uiteindelik het die ark in Jerusalem geëindig waar God se teenwoordigheid en heerlikheid openbaar is (2 Sam 6:12; 1 Kon 8:9-11), terwyl Maria huiswaarts keer en uiteindelik ook in Jerusalem eindig ... in die tempel! (Luk $1: 56 ; 2: 21-22)$.
Wanneer daar na die hoofstroom-kommentare op die Lukasevangelie gekyk word, is hierdie tipologiese lees van Lukas 1:39-25 soos uitgelig in hierdie studie, inderdaad grootliks afwesig (Bock 1994; Fitzmyer 1982; Green 1997). Histories-kritiese eksegese kan bloot nie hierdie tipologie raaksien nie.

Dit beteken natuurlik nie dat 'n groot deel van die kerk dit nie in die geskiedenis wél so gelees en verstaan het, en steeds so lees en verstaan nie. ${ }^{5}$

Hierdie tipologiese lees van Lukas 1:39-56 bevestig die gevolgtrekking waartoe iemand soos Atanasius van Alexandria (296-373 n.C.) alreeds gekom het toe hy van Maria sê: 'You are the Ark in which is found the golden vessel containing the true manna, that is, the flesh in which Divinity resides'. (Roberts, Donaldson \& Coxe 1997:1144). Gregorius die Wonderwerker (213-270 n.C.) skryf: 'For the holy Virgin is in truth an Ark, wrought with gold both within and without, that has received the whole treasury of the sanctuary' (Roberts et al. 1997:1144).

Maximus van Turin (408-23 n.C.) merk op:

But what would we say the ark was if not holy Mary, since the ark carried within it the tables of the covenant, while Mary bore the master of that same covenant? (Ramsay 1989:107)

Johannes van Damaskus (675-749 n.C.) lewer 'n poëtiese voordrag van Maria se dood in een van sy preke vir die Dormitiaanse fees. Hier word die liggaam van Maria as Ark en haar siel as 'n duif uitgedruk:

Today the sacred dove, the pure and innocent soul who was also purified by the Holy Spirit, has flown from the ark - I mean from that body which received God and is the source of our life; and she has found 'a place of rest for her feet' (Gen 8:9), flying up to the intelligible world and pitching her tent in the spotless land of our heritage on high. (Daley 1989:205)

Die Patristiese Dormitiaanse preke lewer ook oorweldigende bewys dat die verbondsark as goddelike troon 'n belangrike tema in die godsdienstige verbeelding van die eerste eeue van die Christendom gebly het. Saam met die gedagte van Maria as verbondsark, is die maagd Maria dikwels as die 'troon van God' beskryf in tekste uit hierdie tyd. Die agtsteeeuse biskop en heilige, Andrew van Kreta, skryf:

She is the throne exalted on high, on which the Lord of Hosts is seated, in the vision of that most far-seeing of all the prophets, Isaiah. (Jes 6:1; Daley 1989:133)

In die voetspore van die kerkvaders kan latere Katolieke eksegete soos Flanagan (1961:372) sê: 'The essential function of the ... ark and our Lady was almost identical - that of being the instrument through which God abode upon earth'. Flanagan

5.Dit is miskien ook van belang om te let op tradisies buite die kerk se aanvaarding van die verhouding tussen Maria en die verbondsark. Metzler (2016:12-74) verwys na die voortgaande ros, alhoewe die Ark van dids dui aan dat die tempel in Jerusalem in antieke lsrael alreeds as 'n baarmoeder of vroulike liggaam gesien is. In die Talmud word die Ark self as ' $n$ aantreklike vroulike liggaam aangedui (vgl Anderson 2009:161-194, 175-176). 
(1961:375) skryf in tipologiese taal: 'all that the ark meant to the Jews, all that and more does our Lady mean to us'.

Die Kategismus van die Katolieke Kerk (Catechism of the Catholic Church) eggo hierdie bevindings van die kerkvaders wanneer daar geskryf word:

Mary, in whom the Lord himself has just made his dwelling, is the daughter of Zion in person, the ark of the covenant, the place where the glory of the Lord dwells. (2676)

Dit is daarom nie vreemd dat daar in die litanie van Loreto die volgende versoek gevind word nie: 'Foederis area' Verbondsark bid vir ons! (Flanagan 1961:374).

Is hierdie sienings van die latere kerk egter in ooreenstemming met die Bybel se eskatologiese verwagting omtrent die kerk?

\section{Bevindings getoets: Maria, die ark en eskatologiese herstel}

Die legitimiteit van 'n tipologiese lees van Lukas, in so mate dat Maria as 'n anti-tipe van die verbondsark vir die kerk na vore tree, kan eers bevestig word indien 'n eskatologiese ondersoek ondersteuning hiervoor bied.

Alreeds in 1936 het Wheeler Robinson daarop gewys dat Joodse eskatologie, soos ander Joodse konsepte, die stempel dra van 'corporate personality' of 'totality'. Die algemene Semitiese geneigdheid om van die individu te praat as die een wat die groep bevat, is reeds deur Robinson (1936:49-96) op die tafel geplaas. Ons het dus in Joodse eskatologie te make met 'n werklike aktualisering van die groep in die individu.

Die Nuwe Testament kan natuurlik ook nie verstaan word sonder dat die eskatologie en genoemde kenmerk van die eskatologie in ag geneem word nie. Om die Jode se geloof te wen, was dit nodig vir die Nuwe Testament om aan te toon dat die eschaton aangebreek het. Dit kon net gedoen word deur tegelykertyd na die Skrif en die nuwe handeling van God in Christus te verwys (Montague 1966:5).

Die vroegste preek van Petrus in Handelinge gebruik Joël se beskrywing van die 'dag van die Here' om die gebeure van Pinksterdag te beskryf (Hand 2:14 e.v.). 'n 'Gerealiseerde eskatologie' is dus sy argument vir geloof en bekering. Terselfdertyd gaan 'n verheerlikte Messias kom om die lewende en die dode te oordeel (Hand 3:19-21; 10:42). Daar is dus ook 'n 'toekomsgerigte eskatologie' in die NuweTestamentiese kerugma (Miller Smith 2010:1-20).

Indien bybelse eskatologie hierdie tweevoudige dimensie bevat, kan gesê word dat die persoon en rol van Maria in die Nuwe Testament onder beide aspekte aangebied word (Montague 1966:20). Matteus 1-2 en Lukas 1-2 openbaar Maria in haar maagdelike moederskap en spesifiek in haar geloofsreaksie as getuienis tot die gerealiseerde eskatologie in die volk van God. Sy is nie net die maagdelike (Jes 7:9 e.v.; 8:23-9:6; 11:1-9) koningin-moeder, voorspel deur Jesaja (Matteus se benadering) nie, maar sy is ook die Dogter van Sion, die oorblyfsel ${ }^{6}$ (vgl. Sef 3:12-13) aan wie die Messias beloof is en uit wie Hy gebore sou word. Sodoende sou Hy die definitiewe inwoning van sy mense inlyf. Hier is Maria as dogter van Sion en verbondsark of tabernakel dus ter sprake.

Dit is juis ook in die aankondiging van Jesus se geboorte aan Maria dat ons hierdie twee punte van eskatologie sien saamvloei: die dogter van Sion en die tabernakel of verbondsark.

Lukas 1:28 begin met: 'wees gegroet' ( $\chi \alpha i p \omega)$. Dit is nie die Griekse vertaling van die gewone Hebreeuse woord vir 'vrede' nie. Wanneer die gebruik daarvan in die Septuagint nagegaan word (Sef 3:14; Joël 2:21; Sag 9:9) blyk dit eerder 'n Ou-Testamentiese term te wees wat Messiaanse vreugde aankondig. Die konteks van al hierdie genoemde gedeeltes is dieselfde. Hulle spreek die Messiaanse volk aan as 'Dogter van Sion' (of in Joël, 'die land Israel'). In hierdie konteks word die koms van Jahweh om in die midde van sy mense te woon, aangekondig. Die punte van ooreenstemming met Sefanja 3:14-17 is aansienlik: 'Jubel', 'Vrees nie', 'die HERE jou God is by jou' as 'koning' en 'verlosser' (Montaque 1966:75-77).

Al hierdie woorde word in die geboorte-aankondiging gevind en stem met die Joodse midrasj-tegniek ooreen wat ons in die Ou Testament vind. Die ooreenstemming van twee gebeure word gesuggereer deur een gebeurtenis te beskryf in terme wat oorspronklik gebruik is om die ander gebeurtenis te beskryf.?

Die punt is dit: Die dogter van Sion het Maria, die 'begunstigde een' geword, en die een wat in haar woon was Jesus, Seun van die Allerhoogste. Selfs die naam Jesus pas in die patroon in, aangesien dit 'Jahwe is Verlosser' beteken. Die Hebreeuse term vir 'in jou midde', in Sefanja, is beqirbek (vgl. Jes 12:6) wat natuurlik ook 'in jou moederskoot' kan beteken (vgl. Gen 25:22).

Dit is in die lig van voorafgaande maklik om te sien hoe die eskatologiese dogter van Sion (Maria) as woonplek van Jahwe, hand aan hand gaan met Maria as verbondsark of tabernakel soos uit die midrasj-uitbeelding van Maria in terme van Dawid se verskuiwing van die ark na Jerusalem uitgewys is. Die verbondsark was die plek van God se teenwoordigheid. Die tema van 'God met ons' (Matt 1:23), is iets wat in Matteus sterk op die voorgrond tree. Gaventa (1995:47) maak die opmerking dat 'for Matthew, the most important function of Mary is to fulfil this prophecy', verwysende na die belofte van Jesaja wat in Matteus 1:23 aangehaal word.

6. Hierdie aktualisering in ' $n$ individu, Maria, van ' $n$ profesie wat oorspronklik gerig is aan die volk van God (kollektief) is natuurlik nie verrassend in die lig van wat reeds gesê is omtrent korporatiewe persoonlikheid nie. Dit is nog minder verrassend as in gese is omtrent korporatiewe persoonlikheid nie. Dit is nog minder verrassend as in gedagte gehou word dat die stad die mense verteenwoordig en die beeld van "n vrou (maagd of Moeder) verteenwoordig dikwels beide (vgl. Klaagl 2:13,19; Jes
$66: 7$; Mig 4:9-10)

7.So byvoorbeeld beskryf die profete die Assiriese oorheesing as ' $n$ terugkeer na die slawerny in Egipte, of Deutero-Jesaja beskryf die terugkeer uit Ballingskap in terme wat oorspronklik vir die Eksodus gebruik is. 
Lukas verkondig aan die kerk van die sestiger- en sewentiger jare n.C. dat die seën van dissipelwees geleë is in die hoor van die woord en die doen daarvan (Luk 8:21). Die model vir daardie geloof is gevind in die reaksie van Maria wat geseënd genoem is vanweë haar geloof en herhaaldelik uitgebeeld word as model vir die aanvaarding van die Woord van God, selfs al was daar nie 'n perfekte begrip van gebeure nie (Luk $1: 38 ; 2: 19,50-51)$.

Daar kan min twyfel bestaan dat Lukas Maria uitbeeld, nie net as die toppunt van Ou-Testamentiese geloof wanneer die 'oorblyfsel' gekonsentreer in een persoon nie, maar ook as model van Nuwe-Testamentiese geloof en daarom van die kerk (Gaventa 1995:69-71). Dit is daarom nie vergesog om tot die slotsom te kom dat die kerk in haar huidige pelgrimstog daarna streef om die geloof van Maria te besit nie. Maria staan vir die eskatologiese doel (toekomstige eskatologie) waarna die kerk streef.

Dit is die moeite werd om op hierdie punt die aandag te fokus op die Evangelie van Johannes. Bo en behalwe die proloog waar die inkarnasie as die eskatologiese beweging van die Woord om by mense te kom woon, uitgelig word, is daar twee ander Maria-gedeeltes wat gelaai is met eskatologiese ondertone, naamlik Johannes 2:1-11 en Johannes 19:25-27. Die debat oor die enigmatiese: 'Wat het ek met jou te doen vrou?'-uitspraak van Jesus, is steeds lewend (Brown 2008:99100; Carson 1991:172-174). Daar kan egter min twyfel bestaan dat die vraag omtrent eskatologie - spesifiek die vraag na die goddelike tydskedule - 'My uur het nog nie gekom nie' (Hartdegen 1960:1993), hier ter sprake is. Die uur van Jesus verwys sonder twyfel na die tyd van sy verheerliking: sy lyding, dood en opstanding (Joh 7:30; 8:20; 12:23,27; 13:1;17:1). Die wonder van die wyn is egter die eerste eskatologiese messiaanse teken. Dit lei sy publieke bediening in en veroorsaak 'n reaksie van geloof by die dissipels (Joh 2:11).

Hierdie gedeelte is deurtrek met eskatologiese vervulling. Die oorvloed wyn sou die teken van messiaanse tye wees (Gen 49:10-12; Amos 9:13-14; ens.). Die waterkanne staan ongetwyfeld vir die Joodse reinigingsrites wat oortref sal word deur die 'nuwe wyn' van die tyd van die nuwe verbond (Gaventa 1995:79-81).

Die verwydering van wyn en die stem van die bruidegom is natuurlik ook tekens van oordeel wat verband hou met die ballingskap (Jer 7:34; 16:9; 25:10; Op 18:23). Die verwydering van die wyn en die verwydering van die bruid en bruidegom gaan hand aan hand, net soos die terugkeer na die land en die herstel van die bruid en bruidegom ook hand aan hand gaan met wyn (Jes 62:5; 8-9; Jer 33:11).

Die groter konteks waarin hierdie gedeelte gevind word, is ook deurtrek met temas van Genesis en die eerste skepping ${ }^{8}$ (Carson 1991:167-168). Op grond hiervan is dit geensins vergesog om in die titel 'vrou', 'n parallel met Eva te sien nie.
In die lig van die belangrikheid van die wysheidsmotief in die Johannesevangelie is dit ook moontlik om 'n sinspeling op Spreuke 9:4-5 te sien waar wysheid (wat as 'n vrou uitgebeeld word) wyn verskaf aan die wat sy uitnooi na haar fees.

Golgota in voleinding, verteenwoordig wat Kana in teken verteenwoordig. Die eggo's van Kana by Golgota is duidelik: die teenwoordigheid van die moeder van Jesus; die aanspreekvorm 'vrou'; die water en die wyn van Kana versus die water en die bloed by Golgota (Gaventa 1995:79-94) en natuurlik ook die 'uur van vervulling'. Natuurlik ook die 'uur van vervulling'. Kyoung-He (2017:55-77) dui ook op uiters oortuigende wyse aan dat Maria die rol van Isak oorneem wanneer Jesus in haar as moeder (verteenwoordiger) van die nuwe volk se plek sterf op Golgota, soos die lam in Isak se plek gesterf het op Moria.

Vir die doeleindes van hierdie studie is die belangrikste: Maria hoort by die eschaton. Johannes se 'gerealiseerde eskatologie' van Maria is gebou op Genesis- en Wysheidsmotiewe waar Lukas weer op die profetiese motiewe van die messiaanse tyd gebou is. Waar Lukas se fokus van belangstelling meer by die misterie van menswording en die geboorte van Jesus lê, lê Johannes se fokus weer op die verlossing en die 'uur' van sy triomf, asook die pynlike geboorte van die nuwe volk van God.

Dit is dan ook nie vreemd dat ' $n$ mens in Openbaring Maria in die eskatologiese voorspelling omtrent die kerk vind nie. Dit is wel so dat sy nie in die vervulling wat gekry word in hoofstuk 21 tot 22 genoem word nie, maar daar kan min twyfel bestaan dat die hemelse Jerusalem in hierdie gedeeltes, identies is met die vrou van hoofstuk 12 (Miller Smith 2010:20-25). Dit is fassinerend as ons in Openbaring 21:9 lees: 'Kom hierheen, ek sal jou die bruid toon, die vrou van die Lam.' En in die volgende vers lees ons: 'En hy het my in die gees weggevoer op 'n groot en hoë berg en my die groot stad getoon, die heilige Jerusalem' (Op 21:10).

Alhoewel daar baie verskil hieroor bestaan, is dit insiggewend dat Openbaring 11:19 eindig met; 'En die tempel van God het in die hemel oopgegaan, en sy verbondsark is in sy tempel gesien' (teen alle verwagting in gegewe die historiese lot van die ark!), en Openbaring 12 begin met die vrou! (Hahn 2001:83 e.v.; Miller Smith 2010:21-32).

Hoe dit ook al sy, volgens Montague (1966:85) kry ons in Openbaring 12 se eerste verse die openingstoneel van die era van die kerk wat beskryf word as 'n pynlike geboorte en die smart van Golgota in herinnering roep (vgl. Miller Smith 2010:101-112). Laasgenoemde was die noodsaaklike voorspel tot die nuwe geboorte van die opstanding. Die kerk op haar pelgrimstog na die hemelse Jerusalem waar daar nie nag of trane gaan wees nie (Op 21:4, 23), moet bemoediging put uit die feit dat die messiaanse era begin het met Golgota se prys, en dat die nuwe geboorte op Paassondagoggend weer uit die geboortepyne van Goeie Vrydag ontspring het. Op daardie historiese oomblik is die beeld van die vrou wat die 
messiaanse volk in pyn gebaar het, nie langer 'n metafoor nie. Nee, soos in Lukas 1-2 is dit gedramatiseer en gerealiseer in die persoon van Maria, die moeder van Jesus. Die hartseer moeder wat die moeder van die dissipels van Jesus, haar nageslag, geword het, is 'n bemoediging vir die kerk onder vervolging en druk. Hoekom? Omdat sy in en as gevolg van haar lyding presies is wat die kerk is: die vrou wat geklee is met die son en swanger met oorwinning, die groot teken van die finale era. Die verbondsark van God in glorie!

\section{Enkele implikasies vir Protestantse nadenke oor die Marialogie}

Indien Lukas 1:39-56 wel daarop dui dat Maria verstaan moet word as anti-tipe van die verbondsark, kan Protestante nie anders as om weer oor die heiligheid van Maria te besin nie.

Die onbevlekte ontvangenis kan ook beredeneer word in die lig van die heiligheid van Maria as anti-tipe van die verbondsark. McKnight (2007:1400) wys daarop dat die leer van die onbevlekte ontvangenis 'n logies-redelike manier is om te verduidelik hoe Jesus Maria se menslikheid deelagtig kon word sonder om haar erfsonde te ontvang. Die bal is dus in die hande van Protestante wat in die erfsonde glo om 'n ander verduideliking hiervoor te vind indien hulle die Marialogie verwerp. Die enigste ander opsie is om dit bloot as misterie te bely, soos die Ortodokse kerk.

In aansluiting hierby word Protestante genoodsaak om te herbesin oor die sogenaamde voortgaande maagdelikheid (the perpetual virginity) van Maria. Vir ons logiese denke bly dit moeilik om te aanvaar. Die herhalende gebruik van $\pi \alpha \rho \theta \dot{\varepsilon} v o \varsigma$ [maagd of jong meisie] in Lukas 1:27, laat ongetwyfeld die klem op haar rein status val, aangesien die woord in die gegewe konteks definitief nie bloot op 'meisie' dui nie.

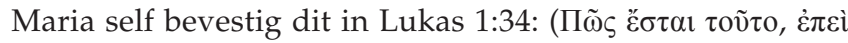

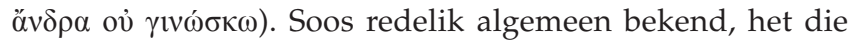

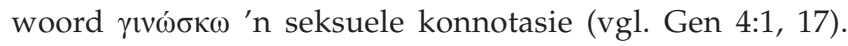
Letterlik kan Maria se reaksie dus vertaal word met: 'Hoe kan dit wees want ek het geen seksuele kennis met enige man nie'.

Tot op hierdie punt was Maria dus ongetwyfeld 'n maagd, maar die klem deur Lukas mag heel waarskynlik daarop dui dat dit haar van hierdie punt af verder ook gekenmerk het, alhoewel dit nie eksplisiet so gestel word nie.

Die vraag is of Josef, indien hy begryp het dat die heerlikheid van God haar oorskadu het soos die wolk van heerlikheid die verbondsark oorskadu het, enigsins seksuele omgang met haar sou gehad het. Sou 'n bewustheid van haar heiligheid hom nie hiervan weerhou het nie?

Indien Maria in die lig van die bevindings in Lukas 1 as antitipe van die verbondsark erken word, kan daar ook weer besin word oor die moontlikheid van die liggaamlike hemelvaart van Maria.
Bybels-teologies kan daar soos volg geredeneer word: Indien Jesus die nuwe Moses is wat 'n nuwe eksodus bewerk het en ons in die hemelse beloofde land inbring met die hemelse Tempel, wat van die verbondsark? Gaan die nuwe verbondsark dan nie ook in die allerheiligste van die hemelse Tempel gevind word nie? As dit Maria is, soos dit in hierdie artikel beredeneer is, is haar liggaam en nie haar siel nie, die verbondsark. Die verbondsark was heilig en het wonderbaarlike eienskappe getoon. Jesus kon waarskynlik net Maria se menslikheid deelagtig word sonder om haar erfsonde te ontvang, indien sy sonder sonde was. Indien dít so is, kan daar beswaar wees teen haar liggaamlike hemelvaart wanneer gelees word dat Henog en Elia liggaamlik opgevaar het? Hahn (2001:83) wys ook op Openbaring 12:1 se verskyning van die vrou nadat Openbaring 11 eindig met die verbondsark in die hemelse Tempel as bevestiging van die feit dat Maria deur die Nuwe Testament gesien is as een wat die rol van die verbondsark oorgeneem het en ook lewend opgevaar het.

\section{Slot}

In hierdie artikel is kortliks aangedui dat eerlike tipologiese hantering van Lukas se opmerkings oor Maria in Lukas 1 ongetwyfeld daartoe lei dat die leser met ' $n$ aanvoeling vir tipologie tot ' $n$ verstaan van die ooreenkoms tussen Maria en die verbondsark kom.

Indien hierdie bevindings aanvaar word, word Protestante genoodsaak om juis in die lig van sola Scriptura te herbesin oor die Marialogie. Kan daar nie in die lig van hierdie artikel 'n nuwe herwaardering kom van Maria as voorbeeld vir die kerk van die eschaton nie, as dissipel en eerste Gees-gedoopte nie? (Hahn 2001:139-142). Kan dit nie gedoen word in die lig van sola Scriptura sonder om in aanbidding van Maria of vertroue in haar te verval, op so ' $n$ wyse wat solus Christus en sola fide in gedrang bring nie?

Hier kan Brown se oproep aan Protestante en Katolieke om die Skrif saam te bestudeer en na mekaar se perspektiewe oor Maria te luister, nie genoeg beklemtoon word nie (Brown 1982:374-379). Om die Skrif só saam te bestudeer met al die jare se agterdog en skeiding waarvan beide partye pynlik bewus is, is natuurlik geen maklike saak nie.

Congar (1964:108-109) het tereg daarop gewys dat die Marialogiese probleem nie opgelos gaan word deur bloot die bereiking van teologiese konsensus met betrekking tot Maria nie. Dit vereis ' $n$ 'bekering' aan beide kante - 'n verandering van denke en hart.

Intellektueel gesproke moet daar aan die een kant 'n bekering plaasvind ten opsigte van verwerping of nalating, en aan die ander kant van oordadigheid. Geestelik behels dit die kweek van vriendskap, saam bid, en die luister na mekaar se standpunte in 'n gees wat vry is van wantroue, vooroordeel en engheid.

Mag hierdie artikel 'n stap wees in dáárdie rigting.

Soli Deo gloria 


\section{Erkenning Mededingende belange}

Die outeur verklaar dat daar geen finansiële of persoonlike verbintenis is met enige party wat hom nadelig kon beïnvloed in die skryf van hierdie artikel nie.

\section{Outersbydrae}

Die outeur was die enigste, betrokke by die skryf van die artikel.

\section{Etiese oorweging}

Hierdie artikel volg alle etiese standaarde vir navorsing.

\section{Befondsing}

Hierdie navorsing het geen spesifieke toekenning ontvang van enige befondsingsagentskap in die openbare, kommersiële of nie-winsgewende sektore.

\section{Data beskikbaarheidsverklaring}

Die deel van data is nie van toepassing op hierdie artikel nie.

\section{Vrywaring}

Die sienings en menings wat in hierdie artikel uitgedruk word, is dié van die outeur en weerspieël nie noodwendig die amptelike beleid of posisie van enige geaffilieerde agentskap van die outeur nie.

\section{Literatuurverwysings}

Anderson, G.A., 2009, 'Towards a theology of the Tabernacle and its furniture', in R Clements \& R. Schwarts (eds.), Text, thought, and practice in Qumran and early Christianity, pp. 161-194, Brill, Leiden.

Aus, D.R., 2016, 'The compassionate father of two difficult sons (Luke 15:11-32) and Judaic interpretation of the Ark and 2 Samuel 6', in A. Avery-Peck, C. Evans \& J. Neusner (eds.), Earliest Christianity within the boundaries of Judaism essays in honor of Bruce Chilton, pp. 241-255, Brill, Leiden.

Baker, D.L., 2010, Two testaments, one Bible: The theological relationship between the Old and New Testaments, 3rd edn., IVP Academic, Downers Grove, IL.

Barth, K., 1965, Church dogmatics, vol. 1, pt. 2, The doctrine of the Word of God, Clark, Edinburgh.

Bock, D., 1994, Luke 1:1-9:50, Baker Academic, New York, NY. (Baker exegetical commentary on the New Testament).

Brown, R., 1982, 'Mary in the New Testament and in Catholic life', America, 01 May, pp. 374-379.

Brown, R.E., 2008, The Gospel according to John (I-XII): Introduction, translation, and notes, vol. 29, Yale University Press, London. (Anchor Yale Bible).

Carson, D.A., 1991, The Gospel according to John, Anchor Yale Bible, InterVarsity, Leicester. (Anchor Yale Bible).

Catholic Church, 1997, Catechism of the Catholic Church, 2nd edn., Libreria Editrice Vaticana, Vatican City.

Congar, Y., 1964, 'Conquering our enmities', in J.A. O'Brien (ed.), Steps to Christian unity, pp. 80-144, Doubleday, Garden City, NY.

Daley, B, 1998, On the dormition of Mary: Early patristic homilies, St Vladimir's Seminary Press, Crestwood, NY.

Day, J., 2005, 'Whatever happened to the Ark of the covenant?', in J. Day (ed.), Temple and worship in Biblical Israel: Proceedings of the Oxford Old Testament Seminar pp. 200-280, Clark, London.

Du Plessis, I.J., 1980, 'Die evangelie van Lukas', in H.J.B. Combrinck, J.L. de Villiers, I.J. du Plessis, A.B. du Toit \& W. Vorster (reds.), Die sinoptiese Evangelies en Handelinge: Inleiding en teologie, pp. 150-162, NG Kerkboekhandel, Pretoria.

Elliott, J.K., 2005, The Protevangelium of James, in the Apocryphal New Testament: A collection of Apocryphal Christian literature in an English translation, Clarendon, Oxford.
Fabiny, T., 2009, 'Typology: Pros and cons in biblical hermeneutics and literary criticism, from Leonhard Goppelt to Northrop Frye', RILCE: Revista De Filología Hispánica 25(1), 138-152.

Faithlife Corporation, 1996a, Septuaginta: With morphology (Eks 40:35), Deutsche Bibelgesellschaft, Stuttgart.

Faithlife Corporation, 1996b, Septuaginta: With morphology, (2 Kgdms 6:1-13), Deutsche Bibelgesellschaft, Stuttgart.

Faithlife Corporation, 1996c, Septuaginta: With morphology, (1 Ch 15:29), Deutsche Bibelgesellschaft, Stuttgart.

Fitzmyer, J.A., 1982., The Gospel according to Luke, I-IX, Anchor Yale Bible, Yale University Press, Yale, MI

Flanagan, M., 1961, 'Mary, Ark of the covenant', Worship 35(6), 370-375.

Gaventa, B., 1995, Mary: Glimpses of the Mother of Jesus, University of South Carolina Press, Columbia, SC

Gentry, P.J. \& Wellum, S.J., 2015, God's kingdom through God's covenants: A concise biblical theology, Crossway, Wheaton, IL.

George, T., 2004, 'The blessed Virgin Mary in evangelical perspective', in C. Braaten \& R. Jenson (eds), Mary, Mother of God, pp. 100-122, Eerdmans, Grand Rapids, MI.

Gerdes, E., 1968, 'Ecumenism and spirituality: A protestant perspective', Theological Studies 29(1), 19-36. https://doi.org/10.1177/004056396802900102

Green, J.B., 1997, The Gospel of Luke, Eerdmans, Grand Rapids, MI. (New International Commentary on the New Testament).

Hahn, S., 2001, Hail, Holy Queen: The Mother of God in the Word of God, Doubleday, New York, NY.

Hartdegen, S., 1960, 'Marian significance of Cana (John 2:1-11)', Marian Studies 11, article 8, 85-103.

Hock, R.F., 2015, 'Response: Luke and the Protoevangelium of James', in V.K. Robins \& J.M. Potter (eds.), Jesus and Mary reimagined in early Christian literature, $\mathrm{pp}$ 253-278, Society of Biblical Literature, Altlanta, GA.

Hollman, M.E., 2015, 'Temple Virgin and Virgin Temple: Mary's body as sacred space in the Protoevangelium of James', in V.K. Robins \& J.M. Potter (eds.), Jesus and Mary reimagined in early Christian literature, pp., 103-128, Society of Biblical Literature, Altlanta, GA.

Knight, J., 2005, Luke's Gospel, Routledge, London.

Kyoung-He, M.K., 2017, 'Mary's mission at the foot of the cross of Jesus in John 19:2528a; in light of Isaac's role in the narrative of Abraham in Genesis 22:1-19', a thesis in partial fulfilment of the requirements for the degree of licentiate of sacred theology with specialization in Marian Studies International, Marian Research Institute University of Dayton, Dayton, $\mathrm{OH}$.

Laurentin, R., 1986, The truth of Christmas beyond the myths: The Gospels and the infancy of Christ, St. Bede's Publications, Petersham, MA.

Louth, A., 2016, 'Pseudonymity and secret tradition in early Christianity: Some reflections on the development of Mariology', St vyimirs Theological Quarterly $60(4), 431-451$.

Lyke, L.L., 2007, I will espouse you forever: The Song of Songs and the theology of love in the Hebrew Bible, Abingdon, Nashville, TN.

McKnight, S., 2007, The real Mary: Why evangelical Christians can embrace the Mother of Jesus, Paraclete Press, Brewster, MA. loc. 1400. Kindle.

Metzler, M.J., 2016, 'The Ark of the covenant and divine rage in the Hebrew Bible', PhD dissertation, Harvard University, Graduate School of Arts \& Sciences, Harvard, MA.

Miller Smith, S., 2010, 'Apocalypticism, eschatology and Revelation 11:19-12:18 Conquering chaos and evil during the apocalypse', thesis submitted to the graduate faculty in partial fulfilment of the requirements for the degree Masters of Arts, Athens, GA.

Montague, G., 1966, 'Our Lady and eschatology', Marian Studies 17, 656-685.

Nestle, E., Nestle, E., Aland, B., Aland, K., Karavidopoulos, J., Martini, C. M. et al., 1993a, The Greek New Testament (27th edn., Lk 1:35), Deutsche Bibelgesellschaft, Stuttgart.

Nestle, E., Nestle, E., Aland, B., Aland, K., Karavidopoulos, J., Martini, C. M. et al., 1993 b. The Greek New Testament (27th edn., Lk 1:41), Deutsche Bibelgesellschaft, Stuttgart.

Oberman, H. 1971, 'The Virgin Mary in evangelical perspective', Journal of Ecumenical Studies 1, no. 2 (1964), 271-298. Republished in The Virgin Mary in evangelical perspective, Fortress Press, Philadelphia, PA.

Ramsay, B., 1989, The sermons of St. Maximus of Turin, ancient Christian writers, Paulist Press, Mahwah, NJ.

Robbins, V.K., 2015, 'Priestly discourse in Luke-Acts', in V.K. Robins \& J.M. Potter (eds.), Jesus and Mary reimagined in early Christian literature, pp. 13-40, Society of Biblical Literature, Altlanta, GA.

Roberts, A., Donaldson, J. \& Coxe, A.C., 1997, The Ante-Nicene Fathers vol. VI: Translations of the writings of the Fathers down to a.d. 325: Fathers of the third century: Gregory Thaumaturgus, Dionysius the Great, Julius Africanus, Anatolius and minor writers, Methodius, Arnobius, Logos Research Systems, Oak Harbor, WA.

Robinson, B.P., 1965, 'Christ as a northern prophet in St. John', Scripture 17, 104-108.

Robinson, W., 1936, The Hebrew conception of corporate personality, Oxford University Press, Oxford.

Shelton, S.J., 2016, 'Overshadowed by the spirit: Mary, mother of our Lord, prototype of spirit-baptized humanity', PhD thesis, Regent University School of Divinity, Pegasus, Regent. 
Stroumsa, G., 2005, Hidden wisdom: Esoteric traditions and the roots of Christian mysticism, Brill, Leiden.

Van Stempvoort, P., 1964, 'The Protevangelium Jacobi: The sources of its theme and style and their bearing on its date', in F.L. Cross (ed.), Studia Evangelica III, pp. 410-426, Akademie, Berlin.
Villeneuve, A., 2016, Nuptial symbolism in Second Temple writings, the New Testament and Rabbinic Literature: Divine marriage at key moments of salvation history, Brill, Leiden.

Vorster, W., 1988, 'The Protevangelium of James and in tertextuality', in T. Baarda (ed.), Text and testimony: Essays on New Testament and Apocryphal literature in honour of A. F. J. Klijn, pp. 262-275, Kok, Kampen. 